\title{
Latin in a Time of Change: The Choice of Language as Signifier of a New Science?
}

Sietske Fransen, University of Cambridge

\begin{abstract}
This essay discusses three authors from the early seventeenth century (Galileo, Descartes, and Van Helmont) and the reasons that guided their decisions to write occasionally in their respective vernacular languages even though Latin remained the accepted language for learned communication. From their writings we can see that their choices were social, political, and always of high importance. The choice of language of these multilingual authors conveyed a message that was sometimes implicit, sometimes explicit. Their usage of both Latin and vernacular proved, on the one hand, their place in the international learned community and, on the other hand, their interest and investment in changing the educational system.
\end{abstract}

$\mathrm{T}$

his essay focuses on the first half of the seventeenth century in Western Europe as the period in which Latin gradually lost its status as the preeminent language of scientific discourse and ceded ground to the European vernaculars. ${ }^{1}$ Authors of scientific texts exhibited a high level of awareness about their choice of language. ${ }^{2}$ This is demonstrated explicitly in their reflections on the use of language and implicitly in their decisions to choose either Latin or a vernacular as the language of their publications. I discuss three examples of famous authors: Galileo Galileo, René Descartes, and Jan Baptista van Helmont. Each was a multilingual author who chose to write and publish his scientific texts in both Latin and his own vernacular. I preface this discussion with a brief exploration of the presence maintained by Latin in the European society of the late sixteenth and seventeenth centuries, as well as the role it played in the scientific community of the time.

Throughout the Middle Ages education in Western Europe was organized by the Catholic Church, with Latin as the language of learning. The impact of Latin on learning continued:

Sietske Fransen is a Postdoctoral Research Associate on the AHRC-funded project "Making Visible: The Visual and Graphic Practices of the Early Royal Society, 1660-1710," at the University of Cambridge. She studies the role of translation of both texts and images in the communication of early modern science. With Niall Hodson and Karl Enenkel she recently edited the volume Translating Early Modern Science (Brill, 2017). Center for Research in the Arts, Social Sciences, and Humanities (CRASSH), Alison Richard Building, 7 West Road, Cambridge CB3 9DT, United Kingdom; sf547@cam.ac.uk.

Acknowledgements. I would like to thank Raphäle Garrod, Sachiko Kusukawa, Andrew McKenzie-McHarg, Katherine M. Reinhart, Richard J. Oosterhoff, and the anonymous referee for useful comments and Michael D. Gordin for his comments as well as for inviting me to contribute. This essay was written with the support of the Arts and Humanities Research Council (AHRC), Grant Reference AH/M001928/1.

${ }^{1}$ For histories of Latin see Françoise Waquet, Latin; or, The Empire of a Sign (London: Verso, 2001); and Jürgen Leonhardt, Latin: Story of a World Language (Cambridge, Mass.: Harvard Univ. Press, Belknap, 2013).

${ }^{2}$ Although the terms "science" and "scientific" are anachronistic for the early modern period, I use them here as general terms for "natural knowledge," which includes among other domains natural philosophy, medicine, astronomy, and mathematics.

Isis, volume 108, number 3. (c) 2017 by The History of Science Society.

All rights reserved. 0021-1753/2017/0108-0008\$10.00. 
everyone who went to school in the late sixteenth and early seventeenth century learned the language. ${ }^{3}$ Moreover, the pupils - all boys - would have received their entire education in Latin. Their teachers spoke to them in Latin; their books were in Latin; they even spoke Latin in class, regardless of whether the school was in the German lands, England, or Italy. ${ }^{4}$ These school years, in which the learning of Latin in all its aspects - reading, grammar, rhetoric, and so forth formed the core of the curriculum, were sometimes followed by a university degree. The courses at this level, as well, were taught entirely in Latin. It therefore does not come as a surprise that the language of communication between learned men (and, sporadically, women) was Latin and that science, as practiced by learned men and women, was conducted in Latin.

While education occurred in Latin, an increasing number of books appeared in vernacular languages. ${ }^{5}$ This development was not new to the sixteenth and seventeenth centuries, as already from the thirteenth century onward texts addressing scientific topics were written in the various European vernaculars. Many of these texts were for practical use: recipes, astrology, manuals for surgery, and the like. ${ }^{6}$ However, the new technology of the printing press set in motion far-reaching developments; the number of books in the vernacular increased in comparison with the number of Latin publications, thereby eroding that language's hegemony. The rising star of the vernaculars (in this case especially Dutch, English, French, German, Italian, and Spanish) coincided with a European-wide movement arguing the ability of these languages to provide a serviceable vehicle for recording and transmitting the practice of science. ${ }^{7}$ The adherents of these changes thus insisted that the vernacular language would serve as well as Latin for communicating scientific knowledge.

The promotion of vernacular languages over Latin in the sixteenth century also had to do with eagerness to change the prevailing system of education. The writings of Jean Bodin, Jan Amos Comenius, Petrus Ramus, Paracelsus, and Francis Bacon all argued for major changes to the university system, including the use of vernacular languages. The changes they envisioned were to impact the methods of teaching, the acquisition of new knowledge (trust in observation in addition to bookish knowledge), and the relative standing of the vernaculars vis-à-vis Latin. ${ }^{8}$ The originally rad-

\footnotetext{
${ }^{3}$ From the sixteenth century onward vernacular education was growing. For an example of education in mathematics in the Dutch case see Charles van den Heuvel, "De vesting als mathematisch en cultureel kennissysteem: Het onderwijs in de vestingbouw aan hovelingen, kooplui en ambachtslieden in de Hollandse Republiek (17e eeuw)," Scientiarum Historia, 2006, 32:99-118. For Germany see Ivo Schneider, "The Concept of Algebra in the Publications of Johannes Faulhaber in the Context of the Activities of the Rechenmeister," in Pluralité de l'algèbre à la Renaissance, ed. Sabine Rommevaux, Maryvonne Spiesser, and Maria Rosa Massa Esteve (Paris: Honoré Champion, 2012), pp. 311-329. On the Italian scuola d'abbaco see Richard J. Oosterhoff, "Neo-Latin Mathematics," in Brill's Encyclopaedia of the Neo-Latin World, ed. Philip Ford, Jan Bloemendal, and Charles Fantazzi, 2 vols. (Leiden: Brill, 2014), Vol. 1, pp. 691-703.

${ }^{4}$ For the teaching of and in Latin see Françoise Waquet, Parler comme un livre: L'oralité et le savoir, XVIe-XXe siècle (Paris: Michel, 2003); Waquet, Latin (cit. n. 1), esp. pp. 19-23; and Leonhardt, Latin (cit. n. 1), esp. pp. 184-227. On the education of girls see Jane Stevenson, "Women's Education," in Brill's Encyclopaedia of the Neo-Latin World, ed. Ford et al., Vol. 1, pp. 87-99.

${ }^{5}$ For a quantification of manuscript and book production see Eltjo Buringh and Jan Luiten Van Zanden, "Charting the "Rise of the West': Manuscripts and Printed Books in Europe, a Long-Term Perspective from the Sixth through Eighteenth Centuries," Journal of Economic History, 2009, 69:409-445.

${ }^{6}$ Ann M. Blair, "La persistance du latin comme langue de science à la fin de la Renaissance," in Sciences et langues en Europe, ed. Roger Chartier and Pietro Corsi (Paris: Ecole des Hautes Etudes en Sciences Sociales, 1996), pp. 21-42, esp. p. 21.

${ }^{7}$ A quick calculation using the data in the English Short Title Catalogue shows that in England the production of Latin titles more than doubled between 1580 and 1680, whereas the production of English titles rose more than nine times: www.estc.bl.uk (accessed 30 Dec. 2016). For a discussion of vernacular languages in early modern Europe see Peter Burke, Languages and Communities in Early Modern Europe (Cambridge: Cambridge Univ. Press, 2004).

${ }_{8}^{8}$ Blair, "La persistance du latin comme langue de science à la fin de la Renaissance" (cit. n. 6), pp. 28-33. On the new pedagogical methods of Comenius see Jan Amos Comenius, The Analytical Didactic of Comenius (Jan Amos Komenský), trans. Vladimir Jelinek (Chicago: Univ. Chicago Press, 1953).
} 
ical idea that the mother tongue might be the best vehicle for understanding belonged to an argument that ran simultaneously in the worlds of scientific communication and the European Reformation while being fed by the strong market in printed book production. ${ }^{9}$ In general, literacy in early modern society increased, which meant that authors could presume a larger audience, made up in part of more readers closer to home. Michael Gordin argues that this rise in literacy might have been a reason for more learned publications in the vernaculars. ${ }^{10}$

During the Middle Ages and the early modern period authors of scientific texts always lived in a bi- if not multilingual society. ${ }^{11}$ Nobody spoke Latin as his or her mother tongue. One effect of higher literacy was the increased translation of Latin scientific works into vernacular languages. ${ }^{12}$ Translation also occurred in the opposite direction, however: from the vernacular into Latin. It was exactly due to an increase in the production of scientific texts in the early seventeenth century that the number of translations between local (vernacular) and international (Latin) languages increased. ${ }^{13}$ The late sixteenth- and early seventeenth-century author thus had a degree of freedom in choosing the language for his scientific writings.

This availability of choice of language can be seen clearly in the correspondence of universityeducated men. Often these men wrote to each other in Latin when they came from different countries and therefore lacked a common vernacular; Latin served as the intermediary language. On the other hand, within the same linguistic region, or when common vernaculars were available, some authors would forgo Latin, as when Jan Baptista van Helmont (1579-1644) corresponded in French with his honorable friend Marin Mersenne (1588-1648), a French priest and natural philosopher who certainly knew Latin. At the same time, Van Helmont wrote in Latin to another French scientist, Pierre Gassendi (1598-1655), to whom he could have written in French. Van Helmont's mother tongue was Dutch, and this language took precedence when he wrote to the authorities at the diocese of Mechelen during the legal proceedings brought against him because of his scientific writings, which were published in Latin. ${ }^{14}$ Van Helmont was no exception in using both Latin and various vernaculars in his scientific correspondence. The first secretary of the Royal Society, Henry Oldenburg (1619-1677), for example, used not only Latin but also German, his mother tongue, as well as French and English in his correspondence. ${ }^{15}$

\footnotetext{
${ }^{9}$ On vernacularization and religion see Alexandra Walsham, "Unclasping the Book? Post-Reformation English Catholicism and the Vernacular Bible," Lournal of British Studies, 2003, 42:141-166; on market forces see, e.g., Ian Maclean, Learning and the Market Place: Essays in the History of the Early Modern Book (Leiden: Brill, 2009).

${ }^{10}$ Michael D. Gordin, Scientific Babel: How Science Was Done Before and After Global English (Chicago: Univ. Chicago Press, 2015), p. 41.

${ }^{11}$ This was also true for the classical period. See J. N. Adams, Bilingualism and the Latin Language (Cambridge: Cambridge Univ. Press, 2003).

12 There is no comprehensive study of all translations made in the early modern period, but the "Renaissance Cultural Crossroads" project has catalogued all translations printed in England between 1473 and 1640, which shows a steady increase in the number of translations. See https://www.hrionline.ac.uk/rcc/; and Sara Barker and Brenda M. Hosington, eds., Renaissance Cultural Crossroads: Translation, Print, and Culture in Britain, 1473-1640 (Leiden: Brill, 2013).

${ }^{13}$ On the translation of vernacular scientific texts into Latin see Peter Burke, "Translations into Latin in Early Modern Europe," in Cultural Translation in Early Modern Europe, ed. Burke and R. Po-chia Hsia (Cambridge: Cambridge Univ. Press, 2007), pp. 65-80. On translating early modern scientific texts in general see Sietske Fransen, Niall Hodson, and Karl Enenkel, eds., Translating Early Modern Science (Leiden: Brill, 2017). Regarding the increase in scholarly books see, e.g., Ian Maclean, "The Market for Scholarly Books and Conceptions of Genre in Northern Europe, 1570-1630," in Learning and the Market Place (cit. n. 9), pp. 9-24, esp. pp. 11-12.

${ }^{14}$ On Van Helmont and his use of language see Sietske Fransen, "Exchange of Knowledge through Translation: Jan Baptista van Helmont and His Editors and Translators in the Seventeenth Century" (Ph.D. diss., Univ. London, Warburg Institute, 2014).

${ }^{15}$ See Henry Oldenburg, The Correspondence of Henry Oldenburg, ed. A. Rupert Hall and Marie Boas Hall, 13 vols., Vols. 1-9 (Madison: Univ. Wisconsin Press, 1955-1973), Vols. 10 and 11 (London: Mansell, 1975, 1977), Vols. 12 and 13 (London: Taylor \& Francis, 1986).
} 
In the seventeenth century there was a definite change in the dominance of Latin within the science community. Ann Blair has located it in the decade between 1630 and 1640 for the French context. ${ }^{16}$ Its consequences can be clearly recognized in the decision that the vernacular would be the medium of communication for two institutions of scientific investigation founded in the 1660s: the Royal Society in London and the Académie des Sciences in Paris. In the case of the Royal Society, Latin was still used extensively in correspondence with those who did not speak English, but the first language of the institution was English. Already in the first half of the seventeenth century authors started to publish more frequently in their vernaculars, although they were still educated in Latin. Once the option of writing in the vernacular was opened, Latin would slowly take on a more passive role in the circulation of knowledge. It became a language that was more read than written. However, the following examples show three scientific authors who were able to alternate smoothly between Latin and their mother tongues in undertaking their scientific work; in the case of Galileo Galilei (1564-1642) this was Italian, for René Descartes (1596-1650) French, and for Jan Baptista van Helmont Dutch. Why did these authors, who all went through a Latin education system, decide on occasion to choose their mother tongues over the customary language of science? How did they attempt to justify their choices, and what was the effect on the reception of their works?

The example of Galileo is interesting, as most of his published work was in Italian, yet this did not impede the rapid spread of his fame far beyond the linguistic borders of that tongue. The dissemination of his works, however, took place especially in Latin - as in the case of one of his first publications, Siderius nuncius (Venice, 1610). ${ }^{17}$ After receiving letters from colleagues in Germany who were not able to read his Italian works, Galileo explained to his friend Paolo Gualdo why he decided to write mainly in Italian:

I wrote in the vernacular because I must have everyone able to read it, and for the same reason I wrote my last book in this language. I am induced to do this by seeing how young men are sent through the universities at random to be made physicians, philosophers, and so on; thus many of them are committed to professions for which they are unsuited, while other men who would be fitted for these are taken up by family cares and other occupations remote from literature.... Now I want them to see that just as nature has given to them, as well as to the philosophers, eyes with which to see her works, so she has also given them brains capable of penetrating and understanding them. ${ }^{18}$

Galileo's eagerness to reach out to those around him who would not have been able to attend university, yet were nevertheless curious to learn more about the world, is touching. But this passage also implicitly reveals his awareness of an increasing literacy among people who missed out on

\footnotetext{
${ }^{16}$ Blair, "La persistance du latin comme langue de science à la fin de la Renaissance" (cit. n. 6), p. 29. The balance between Latin and vernacular did not change at the same pace in every linguistic region; see Burke, Languages and Communities in Early Modern Europe (cit. n. 7), pp. 65-71.

${ }^{17}$ For research on Galileo's influence on the Italian language see Stillman Drake, "Galileo's Language: Mathemathics and Poetry in a New Science," Yale French Studies, 1973, 49:13-27; and Andrea Battistini, "'Girandole' verbali e 'severità di geometriche dimostrazioni’: Battaglie linguistiche ne Saggiatore," Galilaeana, 2005, 2:87-106.

${ }^{18}$ Galileo Galilei to Paolo Gualdo, 16 June 1612, in Le opere di Galileo Galilei, ed. Antonio Favaro et al., 20 vols (Florence: G. Barbèra, 1890-1909), Vol. 11, p. 327, trans. in Stillman Drake, Discoveries and Opinions of Galileo (New York: Anchor, 1957), p. 84. Drake translated "vulgare" as "the colloquial tongue," which I changed to "the vernacular," a term now more commonly used.
} 
a Latin education and were therefore outsiders to the knowledge communicated in that language. Galileo made a clear statement against the learned "filuorichi" (philosophers) and their Latin language, which rendered the content inaccessible to many. However, many people outside of Italy were not able to understand his Italian, which in turn meant that most of his Italian works were (quickly) translated into Latin, thus enabling them to reach a wider audience. ${ }^{19}$

With Descartes, we are dealing with an author who struck more of a balance in his decisions to write and publish either in Latin or in his mother tongue. According to the editors of his letters, more than half of them are in French. Descartes used Latin for formal letters, especially, as well as when writing to non-French correspondents. ${ }^{20}$ His publications, too, were written in both Latin and French. His first published work, the Discours de la méthode (1637), appeared in French and includes a passage, in Part 6, in which Descartes explains why he chose to write in his mother tongue. Descartes states that he is writing in French, "la langue de mon pais [the language of my country]," and not in Latin, "celle de mes Preceptuers [(the language) of my teachers]." The division between those who read French and those who read Latin was rendered in a more polemical tone when Descartes expressed his hope that those who had "natural minds" (raison naturelle - i.e., the less educated readers of French) might judge his ideas more positively than those who based their knowledge entirely on books. ${ }^{21}$ Descartes was not only writing for a French audience, seeking to educate them; he also expected them to be more receptive to his ideas because their thinking remained uncluttered by scholastic learning. His choice of language can therefore be interpreted as a provocation aimed at the old-fashioned scholasticism of his teachers (and university teaching more generally) and in support of the new style of science, which according to its defenders relied on the human ratio for analysis and interpretation.

Seven years after the publication of the French Discours, however, a Latin translation appeared under the title Specimina philosophiae. In a brief letter to the reader Descartes says: "Haec specimina Gallicè à me scripta, et ante septem annos vulgate, paullò post ab amico in linguam Latinam versa fuere, ac versio mihi tradita, ut quicquid in ea minus placeret, pro meo jure mutarem."22 Although Descartes had his reasons for writing in the language of his own country, it was the Latin translation produced by a colleague and corrected by Descartes himself that formed the text most "seventeenth-century Cartesians and eighteenth-century historians of philosophy" used. ${ }^{23}$ This demonstrates again how Latin retained its function as the language for the international communication of science.

\footnotetext{
${ }^{19}$ Translation between vernacular scientific texts also happened; see Isabelle Pantin, "The Role of Translations in European Scientific Exchanges in the Sixteenth and Seventeenth Centuries," in Cultural Translation in Early Modern Europe, ed. Burke and Hsia (cit. n. 13), pp. 163-179.

${ }^{20}$ René Descartes, The Philosophical Writings of Descartes, Vol. 3: The Correspondence, ed. John Cottingham, Robert Stoothoff, and Dugald Murdoch (Cambridge: Cambridge Univ. Press, 1991), p. x.

${ }^{21}$ René Descartes, Discours de la méthode (Leiden: Ian Maire, 1637), p. 77.

22 "After these ideas were written by me in French, and first existed seven years in the vernacular, a little later they were turned into the Latin language by a friend, and the translation was delivered to me, so that I could change according to my judgment anything that did not quite please me.” René Descartes, Specimina philosophiae (Amsterdam: Louis Elzevir, 1644), sig. [b4]v. (Here and throughout this essay, translations are mine unless otherwise indicated.) For a full edition and analysis of the Specimina philosphiae see C. L. Vermeulen, "René Descartes, Specimina philosophiae: Introduction and Critical Edition" (Ph.D. diss., Utrecht Univ., 2007).

${ }^{23}$ Vermeulen, "René Descartes, Specimina philosophiae," p. 29. See also Jean-Luc Marion, "Ouverture: Descartes aujourd'hui," in Problématique et réception du "Discours de la methode" et des "Essais," ed. Henry Méchoulan (Paris: Vrin, 1988), pp. 9-22, esp. pp. 20-21.
} 
My final example is the above-mentioned physician from Brussels, Jan Baptista van Helmont. In the introduction to his posthumously published medical book Ortus medicinae, Van Helmont sets out his view that a person's mother tongue is the language most conducive to the formation of ideas: "Verum enimvero omnis primae cogitationis obiectum, in verba abiens, in vernacula prius semper haberi, ... vidi ... Germanum aegrotantem sedentem vel iacentem, prout ipsum collocarent, sculptilis ad instar, qui nunquam ad interrogata reponere compos erat, nec intelligebat, quae vel eius uxor vel natorum quis alia quam propria lingua pronunciarent, cum tamen intra domesticos parietes jugiter uteretur Italica lingua et Gallica." Van Helmont provides an interesting observation indicating how people's immediate thoughts find expression in their mother tongue: an injured or sick man reverts to speaking only his mother tongue even though he used to speak other languages daily. Van Helmont went so far as to claim that if men indeed conceived their first ideas in their mother tongue, then any rendering in another language would be "animae inconveniens et mirum [unsuitable and strange to the soul]."24

Yet Van Helmont overtly contradicted himself by writing most of his texts in Latin, which in accordance with his own ideas about language represented a laborious and stilted mode of expression. Van Helmont did not reveal much about his practical reasons for writing in two languages. But in the introduction to the German translation of the Ortus medicinae, Christian Knorr von Rosenroth (1636-1689), the translator and a friend of Van Helmont's son, noted that Van Helmont had intended to write all his works in his mother tongue. ${ }^{25}$ However, he went on to explain, Van Helmont was daunted by the prospect of having to invent many new phrases (Redens-Arten) to express his ideas. Van Helmont gave up his Dutch effort (printed as Dageraed [Amsterdam, 1659]) and wrote the bulk of his work in Latin. Apart from the idea of primacy of the mother tongue, Van Helmont also expressed a wish to write for his neighbors, and thus the local community, which would not necessarily have had access to Latin.

We have already seen this inclination to communicate with a local or regional audience in the vernacular and with a more international audience in Latin, showing that the different languages had different roles. ${ }^{26}$ In the case of Van Helmont it also brings to the fore how authors negotiated the challenges and opportunities presented by multilingualism. After so many years of a monolingual Latin education and an entire medical degree in Latin, this language must have been the first and preferred language when it came to his professional occupation. Van Helmont was not trained to write about medicine in Dutch and might therefore have found this harder and, indeed, "strange" (mirum) to his soul. Despite his own ideas about mother tongue and familiarity, Van Helmont's choice of language in practice indicates the enduring role of Latin as a language for scientific communication in early modern Europe, closely tied to the processes of education.

\footnotetext{
24 “That certainly every idea of first understanding, being changed into words, occurs always first in the mother tongue, ... I have witnessed . . . in a German man, who, being ill and sitting or lying like a statue, just as they put him, was unable to reply to questions, nor did he understand what his wife or any of his children said in another than his proper language, although he usually spoke Italian and French at home." Jan Baptista van Helmont, Ortus medicinae (Amsterdam: Louis Elzevir, 1648), sig. 3*r. This introduction was initially written in Dutch; it was translated into Latin by Van Helmont's son and included in the first (posthumous) publication of the Ortus medicinae.

${ }^{25}$ Jan Baptista van Helmont, Aufgang der Artzney-Kunst, trans. Christian Knorr von Rosenroth (Sulzbach: Johann Andreae Endters Sel. Söhne, 1683), sig. )( iii[verso].

${ }^{26}$ See also Isabelle Pantin, "Latin et langues vernaculaires dans la littérature scientifique européenne au début de l'époque moderne (1550-1635)," in Sciences et langues en Europe, ed. Chartier and Corsi (cit. n. 6), pp. 43-58.
} 
An examination of the role of Latin as a language of science in the seventeenth century demonstrates that it always operated in conjunction with other languages. ${ }^{27}$ More than in earlier centuries, Latin as a language of education was joined by rising literacy in vernaculars. Authors of scientific texts were in fact multilingual and were therefore in many instances in a position to decide whether they were writing for an international audience of the university-educated learned or whether they were more interested in addressing a local audience in their mother tongue (or a second vernacular). This choice was contingent on many factors.

Chief among them was the question of audience. In the examples discussed, we have seen that there was an idealistic reason for writing in one's mother tongue: to reach a local audience that did not necessarily know Latin but was nevertheless interested in and entitled to the knowledge the author intended to share. Writing for fellow speakers of one's mother tongue had also, as Descartes and Van Helmont explained, a philosophical and political aim, since those readers had not been corrupted by scholastic learning and might therefore be more receptive to new ideas than those who went to university. This decision was therefore at times polemical and provocative, as it implicitly challenged more conservative institutions of traditional learning.

All in all, the choice of language for writing science had a major impact on the reception of these works in terms of the initial audience and the authority bestowed by the particular language. As we have seen, most works would eventually reach the European community at large after publication in Latin, not through the vernacular. Latin was therefore an intermediary and hegemonic language for science, hugely important for international communication and exchange in the seventeenth-century scientific community. Since there was as yet no alternative international language that could take over that role, Latin retained its dominant place. Authors who had a choice of language were able to put their multilingualism to use in order to reach various audiences, while making statements-implicit or more overt-about new directions in science.

\footnotetext{
${ }^{27}$ See also Ann Moss, "Being in Two Minds: The Bilingual Factor in Renaissance Writing," in Proceedings of the Eighth International Congress of Neo-Latin Studies, Copenhagen, 12 August to 17 August 1991, ed. Rhoda Schnur (Binghamton: State Univ. New York Press, 1994), pp. 61-74.
} 